\title{
A Method for Characterizing Urban Forest Composition and Structure for Landscape Architects and Urban Planners
}

\author{
Joe R. McBride
}

\begin{abstract}
A method combining numeric data collection with the preparation of street tree cross-sections and plans, based on surveys of 33 urban forests around the world, is reviewed. The combination can provide design professionals with graphic
\end{abstract} information on urban forest structure not collected by more traditional methods for urban forest inventories.

Key Words. Composition; planting space; species frequency; street cross-section; street plan; structure; tree spacing.

\begin{abstract}
An urban forest can be characterized in terms of composition, structure, and function (Rowntree 1984). Composition is usually characterized by identifying the species that are present and the contribution (number of individuals or percent) of each species to the total tree population. Structure is usually defined in terms of tree size, canopy cover, and the spacing of trees along streets and in parks. These characteristics are useful in describing an urban forest and for understanding the functional roles of urban forests. However, they do not provide information on other structural characteristics that are of interest to landscape architects concerned with urban forest design. This article reports on a method developed to collect information on urban forest composition and structure of interest to landscape architects. The specific information addressed includes 1) species frequency; 2) tree spacing; 3) dimensions of planting spaces; 4) tree height in relation to adjacent building height; 5) height to live crown; 6) radial spread of trees in relation to the adjacent streets, sidewalks, and buildings; and 7) tree planting patterns along streets.
\end{abstract}

\section{BACKGROUND OF STUDY}

The method reported here was developed for a study of the urban forest composition, structure, and function in 33 of the world's cities (McBride 2000). It investigated the relationships between urban forest characteristics and the biomes in which cities occurred. One hypothesis of the study was that structural characteristics of an urban forest might be influenced by the characteristics of the biome. For example, would one expect to find a greater frequency of trees with horizontally spreading branches in cities in the desert and savanna biomes where shading of streets and sidewalks would be a valuable structural dimension?

Arborists have systematically collected structural information on urban forests as a part of street and park tree inventories (Miller 1997). Tree diameter, height, live crown ratio, crown diameter, and tree condition are commonly recorded in these surveys. Street tree inventories are usually conducted for an entire city or subsection of a city. Sample inventories have been developed to more efficiently acquire information about composition and structure. The distribution of sample sites has followed simple random sampling, randomized block sampling, systematic random sampling, and two-staged sampling (Panahi et al.
2003). A few studies have attempted to determine the sample size necessary to estimate various compositional and structural characteristics of an urban forest. Nowak et al. (2003) suggested a minimum sample of 200 plots is needed to determine percent species composition in large cities.

Trees have been used as design objects in urban environments since the establishment of cities. Their use as aesthetic objects has ranged from the individual specimen tree that resembles sculpture to large numbers of trees unifying and enhancing the visual properties of streets, boulevards, and parks. Countless outdoor spaces in cities are defined by trees. As objects of design, they provide variation in size, shape, color, and texture. The use of trees in urban design has been documented by Arnold (1993). He describes the design qualities of trees along avenues, streets, and in parks and public spaces other than parks (e.g., parking lots, traffic islands, medians). Arnold contrasts eight geometric patterns grouping trees in small parks using examples from the United States and Europe. He also reviews the design element of trees used in larger urban parks using Central Park in New York City, U.S., as an example. Jacobs et al. (2002) provides an account of how trees have been used as design elements along boulevards in cities around the world. These and other works (Gruffydd 1987; Littlewood 1988; Tsuru 1992; Zion 1995; Trowbridge and Bassuk 2004) treating the use of trees in urban design should be consulted for details of tree species selection, spacing, and planting patterns in common use.

\section{METHOD}

A block-long unit of a streetscape was used as a sampling unit in this study. The streetscape may be defined as the area between buildings along a street. It includes the facades of the buildings, front yards (in the case of residential neighborhoods), sidewalks, driveways, curbside planting strips, and the street. It may be modified as an environment for trees by stormwater drainage features, utility lines, transit stops, and parking areas. The blocklong streetscape was chosen as a sample unit because it usually represents a unit of a design plan for a larger section of a street or boulevard. This block-long unit may be similar to adjacent blocks for the entire length of a street or individual blocks may differ as one moves along a street. Most city blocks exhibit some 
unity in tree spacing, tree growing space, sidewalk and street dimensions, and the type of buildings. Capturing that unity of design for typical streetscapes was the objective of the method developed here. The length of a city block varies considerably within and among cities. No standard block length was adopted for this study, but the blocks studied typically were 50 to $100 \mathrm{~m}$ (165 to $330 \mathrm{ft})$ long.

Sampling sites were initially located on a random basis by laying a grid over a map of a city and picking 50 intersection points of the grid lines using a table of random numbers. In the initial application of this approach, it was found that a large percentage of the city blocks selected at random did not support any street trees. This method was abandoned in favor of a procedure in which local urban forest experts were asked to suggest a number of streets and boulevards that represented the range of tree characteristics in their city. Between 20 and 40 sites (both recommended and selected during the city survey) were sampled in each city. In some cities, additional sampling sites were selected to include historically significant examples of the urban forest. The final selection of sampling sites cannot be considered a random selection and, therefore, statistical comparisons of the data are not justified. However, the frequencies of occurrence of tree species were calculated and modal tree spacing and modal dimensions of planting spaces were identified. Comparisons of these frequencies of occurrence of individual tree species to published species rankings based on complete tree inventories in some of the cities studied suggest the method of sampling provided a fairly accurate estimate of the more commonly used tree species. The species area curve used by botanists was applied to the data on tree spacing and dimensions of planting spaces to test the adequacy of the method for collecting data on these two characteristics.

At each sample site, the following information was recorded for each tree species present: 1) diameter at breast height; 2) tree height; 3) height to the base of the live crown; 4) crown radius; 5) tree spacing; and 6) growing space. Tree canopy closure along and across the street, planting pattern, approximate tree age, tree condition, and adjacent building type, height, and age were also noted. Ocular estimates of tree dimensions were made after initial daily calibration of the eye with a diameter tape, clinometer, and measuring tapes (for crown radius and growing space). Tree spacing was determined by pacing as were street and sidewalk widths. These were also checked each day with a measuring tape. The information was recorded on a data form shown in Figure 1.

Additional structural information was recorded by preparing a cross-section sketch of each streetscape. A plan was drawn if the trees had not been planted in a manner that could be represented by the numeric data and the cross-section sketch. For example, some streetscapes studied had trees planted in bulb outs (an extension of the streetside planting strip into the street to provide space for planting space for a tree) into the street as well as along the sidewalk. In sections, these would appear as two rows of trees, but the bulb outs were limited to the ends of the block. The cross-section sketch showed the dimensions of various elements of the streetscape (lawn width, sidewalk width, street width, width of median in the case of boulevards, and any elevation differences across the streetscape). Other features such as overhead utility lines or features of the facades of buildings (e.g., awnings) that might interfere with tree growth were included in the cross-section sketch. Outlines of trees were drawn on the

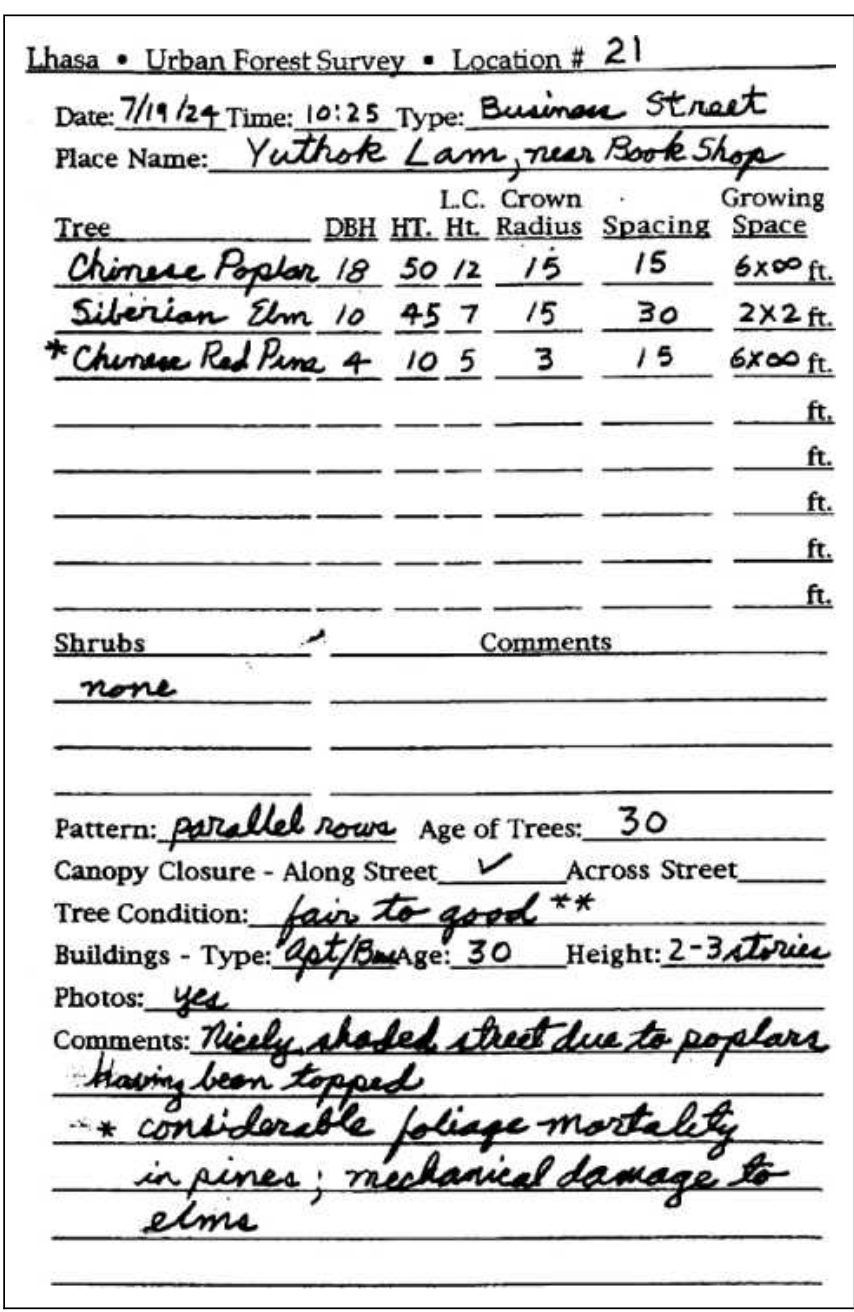

Figure 1. Data form (data from Yuthok Lam, and Lhasa).

cross-section sketch to show tree size in relation to the streetscape. The extent of the tree canopy over the sidewalk and street and the relation of the crown to adjacent buildings were illustrated. Examples of a cross-section diagram and a streetscape plans are shown in Figures 2 and 3. A variety of forms involving grid paper were tested during the study, but it

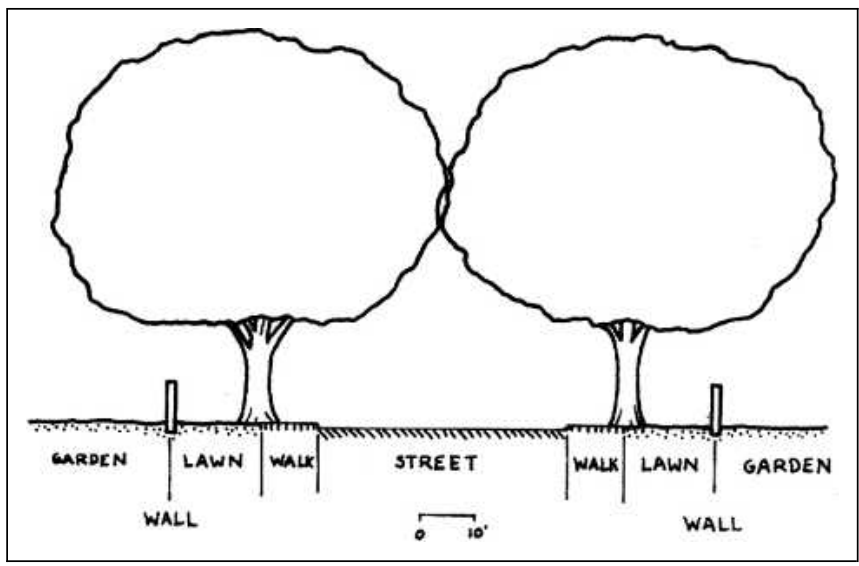

Figure 2. Cross-section sketch of Niti Marg and New Delhi. 


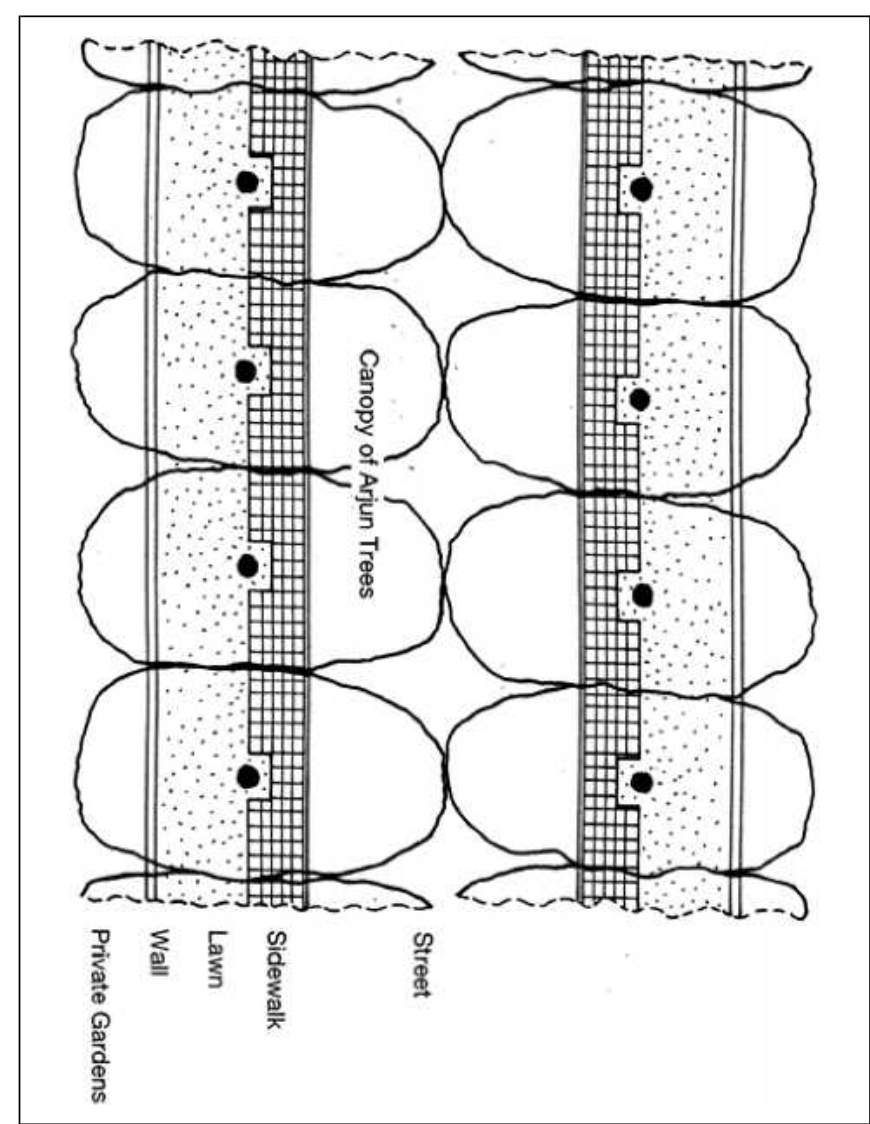

Figure 3. Plan of Niti Marg and New Delhi.

became apparent that the cross-sections could be drawn more efficiently on a blank sheet without attempting to draw them to scale. The sketches did attempt to show the relative size of trees to the other elements of the streetscape. Street width, sidewalk width, and size of other relevant elements were noted on the sketches.

\section{EXAMPLES OF DATA COLLECTED}

\section{Species Composition}

Landscape architects are interested in tree species that may be used in urban design as well as the dimensions of various elements of local streetscapes. The method described here yields information on the species of trees occurring along streets in urban areas. One approach to summarizing the tree species data is to calculate the frequency of occurrence of each tree species. Frequency of occurrence is defined as the number of sample sites where a given tree species occurs divided by the total number of sites sampled. The average percent frequency of occurrence of the three most frequently encountered street tree species in each of three cities in each biome averaged 34.3 with a range from 21.7 to 55.0 (Table 1). One conclusion drawn from these frequencies is that relatively few species are widely planted in each biome. Among commonly encountered species were angsana (Pterocarpus indicus) in the tropical forest biome, London plane (Platanus acerifolia) in the deciduous forest biome, Canary Island date palm (Phoenix canariensis) in the desert biome, and rowan (Sorbus aucuparia) in the tundra biome.
Table 1. Frequency of occurrence by biome of the top three most commonly encountered tree species in each city.

\begin{tabular}{lll}
\hline Biome & $\begin{array}{l}\text { Average } \\
\text { frequency of } \\
\text { occurrence }^{\mathrm{z}}\end{array}$ & $\begin{array}{l}\text { Range of average } \\
\text { frequency of } \\
\text { occurrence }^{\mathrm{z}}\end{array}$ \\
\hline Tropical forest & 25.6 & $38-13$ \\
Broadleafed evergreen forest & 21.7 & $39-15$ \\
Deciduous forest & 36.4 & $56-13$ \\
Coniferous forest & 35.7 & $80-16$ \\
Mixed deciduous-coniferous forest & 40.4 & $59-27$ \\
Mediterranean woodland/scrub & 27.5 & $32-19$ \\
Savanna & 29.2 & $24-14$ \\
Grassland & 30.9 & $83-18$ \\
Desert & 40.9 & $71-16$ \\
Tundra & 55.0 & $91-6$ \\
Highland & 33.7 & $67-21$ \\
Average & 34.3 & $58.2-16.2$ \\
\hline
\end{tabular}

${ }^{\mathrm{z}}$ Of the three most commonly encountered street tree species in each city.

\section{Modal Tree Spacing}

Tree spacing and the dimensions of planting spaces used in different cities for planting boulevard and street trees are shown in Tables 2 and 3. These data indicate that wider tree spacing is generally used in the planting of the medians in boulevards. Medians are usually wider than strips for street tree planting and the widths of tree wells. Greater spacing of trees in boulevard medians may stem from an interest in using larger trees in medians for both aesthetic and practical purposes such as the shading of boulevards. Wider space is needed for these trees to provide adequate development of their large crowns. Wider spacing is also recommended by some traffic engineers as a safety feature. Wider spacing avoids the "palisade effect" that occurs when a row of closely planted trees is viewed from a narrow angle. The "palisade effect" can prevent motorists from seeing cross-traffic or pedestrians approaching intersections.

The modal distance for the spacing of trees in boulevard medians was $12 \mathrm{~m}(39.6 \mathrm{ft})$ for the cities in the study of the world's

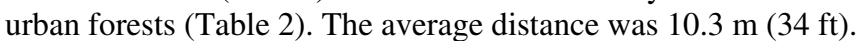
In contrast, the modal and average distances measured for street trees were 10 and $7.3 \mathrm{~m}$ (33 and $24.1 \mathrm{ft}$ ), respectively. The modal spacing is of significance to landscape architects because it is the most commonly found spacing in a city. Although one can calculate the average spacing, that spacing does not actually exist in a city and is not a value of use to the designer. The closer spacing generally used for street trees is a reflection of the potential size of the tree crown at maturity. A continuous crown canopy above the sidewalk is desired for shading pedestrians in most cities. The reduced growing space along streets, in contrast to the space available in most boulevard medians, dictates the use of smaller trees.

Medians in boulevards, streetside planting strips, and tree well cuts into sidewalks for tree planting varied considerably among the cities studied (Table 3 ). The modal boulevard-median planting strip width was $2 \mathrm{~m}(6.6 \mathrm{ft})$. The range of modal widths varied from 1.5 to $40 \mathrm{~m}$ ( 5 to $132 \mathrm{ft}$ ). In two of the cities studied, the median strips were always paved and tree wells either $3 \times 1$ $\mathrm{m}(9.9 \times 3.3 \mathrm{ft})$ or $2 \mathrm{~m}(6.6 \mathrm{ft})$ in diameter were used.

The modal width of planting strips in the cities studied was 2 $\mathrm{m}(6.6 \mathrm{ft})$ and modal planting strips along streets ranged in width from 0.3 to $10 \mathrm{~m}$ ( 1 to $33 \mathrm{ft}$ ). The modal tree well was $1.2 \times 1.3$ $\mathrm{m}(4 \times 4.3 \mathrm{ft})$. The size of these tree wells varied from $0.3 \times 0.3$ 
Table 2. Modal tree spacing along boulevards (trees in medians) streets.

\begin{tabular}{|c|c|c|c|c|}
\hline \multirow[b]{2}{*}{ Biome/city } & \multicolumn{2}{|c|}{ Boulevard } & \multicolumn{2}{|c|}{ Street } \\
\hline & $\begin{array}{l}\text { Modal } \\
(\mathrm{m})\end{array}$ & $\begin{array}{l}\text { Range } \\
(\mathrm{m})\end{array}$ & $\begin{array}{l}\text { Modal } \\
\text { (m) }\end{array}$ & $\begin{array}{l}\text { Range } \\
(\mathrm{m})\end{array}$ \\
\hline \multicolumn{5}{|l|}{ Tropical forest } \\
\hline Bangkok & 7.5 & $6.5-8$ & 6 & $4-13.3$ \\
\hline Rio de Janeiro & 12 & $13-20$ & 7.5 & $3-13.3$ \\
\hline Singapore & 12 & $3-33$ & 10 & $5-26$ \\
\hline \multicolumn{5}{|c|}{ Broad-leafed evergreen forest } \\
\hline Hong Kong & 10 & $8-13.3$ & 4 & $3-8$ \\
\hline Sydney & 15 & 15 & 12 & $5-20$ \\
\hline Tokyo & 7.5 & $8-10$ & 7.5 & $6-13.3$ \\
\hline \multicolumn{5}{|c|}{ Deciduous forest } \\
\hline London & 12 & 12 & 12 & $6-20$ \\
\hline New York & 12 & $10-13.3$ & 7.5 & $8-14$ \\
\hline Paris & 11.5 & $10-13$ & 6 & $5-6$ \\
\hline \multicolumn{5}{|c|}{ Coniferous forest } \\
\hline Jacksonville & 12 & $10-13.3$ & 7.5 & $3-13$ \\
\hline Seattle & 10.5 & $8-12$ & 5 & $4-12$ \\
\hline Vancouver & 12 & $8-13.3$ & 10 & $4-13$ \\
\hline \multicolumn{5}{|c|}{ Mixed deciduous-coniferous forest } \\
\hline Beijing & 2 & 2 & 5 & $2-6$ \\
\hline Moscow & 6 & $2-8$ & 6 & $2-8$ \\
\hline Stockholm & 8.5 & $3-20$ & 10 & $8-18$ \\
\hline \multicolumn{5}{|c|}{ Mediterranean woodland/scrub } \\
\hline Athens & 10 & $5-12$ & 5 & $3-7$ \\
\hline Los Angeles & 15 & $6-40$ & 5 & $5-12$ \\
\hline Tel Aviv & 20 & $12-22$ & 12 & $8-13.3$ \\
\hline \multicolumn{5}{|l|}{ Savanna } \\
\hline Brasilia & 12 & 10-72 & 10 & $5-16$ \\
\hline Lagos & 10.5 & $8-13.3$ & 6 & $4-10$ \\
\hline New Delhi & 12 & $3-20$ & 20 & $10-20$ \\
\hline \multicolumn{5}{|l|}{ Grassland } \\
\hline Buenos Aires & 12 & 12 & 10 & $2-20$ \\
\hline Johannesburg & 23 & $10-23$ & 13.3 & $10-23$ \\
\hline Tehran & 6 & $2-12$ & 4 & $4-6$ \\
\hline \multicolumn{5}{|l|}{ Desert } \\
\hline Cairo & 12 & $3-13,3$ & 5 & $2-13.3$ \\
\hline Dubai & 11 & $5-16$ & 6 & $6-8$ \\
\hline Phoenix & 15 & $6-33$ & 6 & $6-16$ \\
\hline \multicolumn{5}{|l|}{ Tundra } \\
\hline Murmansk & 2 & $2-2.5$ & 6 & $2-8$ \\
\hline Nuuk & NA & NA & NA & NA \\
\hline Reykjavik & NA & NA & 6 & $2-10$ \\
\hline \multicolumn{5}{|l|}{ Highland } \\
\hline Cusco & 13.3 & $10-14$ & 5 & $3-10$ \\
\hline Lasha & NA & NA & 5 & $4-6$ \\
\hline Quito & 15 & $5-42$ & 7 & $5-18$ \\
\hline
\end{tabular}

$\mathrm{NA}=$ not applicable.

$\mathrm{m}(1 \times 1 \mathrm{ft})$ to $2.3 \times 2.4 \mathrm{~m}(7.6 \times 7.9 \mathrm{ft})$. The modal circular tree well was $2 \mathrm{~m}(6.6 \mathrm{ft})$ in diameter with a range from 0.3 to $2.4 \mathrm{~m}$ ( 1 to $7.9 \mathrm{ft}$ ) in diameter. It was discouraging to see that small planting spaces were being used in many cities. Often these smaller planting strips and tree wells showed evidence of sidewalk damage by tree roots and injury to the trees by the restrictions of the growing space. London plane trees growing in tree wells under $1.2 \times 1.2 \mathrm{~m}(4 \times 4 \mathrm{ft})$ caused damage to the adjacent sidewalks and curbs in Palo Alto, California (McBride 2003). Studies by Urban (1989) suggest that $2 \times 2 \mathrm{~m}(4 \times 4 \mathrm{ft})$ tree wells are necessary to sustain long-term tree growth.
Table 3. Modal boulevard median width and street tree well dimensions.

\begin{tabular}{|c|c|c|c|c|}
\hline \multirow[b]{2}{*}{ Biome/city } & \multicolumn{2}{|c|}{ Boulevard median width } & \multicolumn{2}{|c|}{ Street tree well } \\
\hline & Modal (m) & Range (m) & Modal (m) & Range (m) \\
\hline \multicolumn{5}{|l|}{ Tropical forest } \\
\hline Bangkok & 2 & 2 & $1.2 \times 2$ & $1 \times 1-2 \times 6$ \\
\hline Rio de Janeiro & 2 & $2-13$ & $1 \times 1$ & $1 \times 1-1 \times 2$ \\
\hline Singapore & 5 & 5 & $2.5 \times 2.5$ & $2 \times 6-2 \times 3$ \\
\hline \multicolumn{5}{|c|}{ Broad-leafed evergreen forest } \\
\hline Hong Kong & 2 & 2 & $1 \times 1$ & $1 \times 1-1 \times 22$ \\
\hline Sydney & 10 & 10 & $1.2 \times 2$ & $0.6 \times 0.6-1 \times 2$ \\
\hline Tokyo & 1.5 & $1.5-6.5$ & $1.5 \times 1.5$ & $1 \times 1-1.5 \times 2$ \\
\hline \multicolumn{5}{|c|}{ Deciduous forest } \\
\hline London & 8 & 8 & $0.6 \times 1$ & $0.6 \times 0.6-1 \times 3$ \\
\hline New York & 2 & $2-3.5$ & $1.2 \times 2$ & $0.6 \times 1-2 \times 3$ \\
\hline Paris & NA & $5-8 \mathrm{NA}$ & 2 (dia.) & 2 (dia.) \\
\hline \multicolumn{5}{|c|}{ Coniferous forest } \\
\hline Jacksonville & 5 & $5-8$ & $1.5 \times 2$ & $1 \times 1-2 \times 2$ \\
\hline Seattle & 3 & $2.5-3.5$ & $1.2 \times 1.2$ & $1.2 \times 1.2-1.2 \times 2$ \\
\hline Vancouver & 3 & $2-3$ & $1.2 \times 2$ & $1 \times 1-1.2 \times 2$ \\
\hline \multicolumn{5}{|c|}{ Mixed deciduous-coniferous forest } \\
\hline Beijing & 1 & $1-1.5$ & $1 \times 1$ & $1 \times 1-3 \times 3$ \\
\hline Moscow & 40 & $12-40$ & NA & NA \\
\hline Stockholm & 3.3 & $5-8$ & $1 \times 1.2$ & $1 \times 1-1.2 \times 1.2$ \\
\hline \multicolumn{5}{|c|}{ Mediterranean woodland/scrub } \\
\hline Athens & 1 & $3-7$ & $1 \times 1$ & $0.5 \times 0.5-1 \times 1$ \\
\hline Los Angeles & 3.3 & $1.5-11$ & NA & NA \\
\hline Tel Aviv & 12 & $10-20$ & $1 \times 1$ & $0.6 \times 2$ \\
\hline \multicolumn{5}{|l|}{ Savanna } \\
\hline Brasilia & 3.3 & $5-7$ & $1 \times 1$ & $0.6 \times 0.6-2.2 \times 2.2$ \\
\hline Lagos & 2 & $2-3$ & NA & NA \\
\hline New Delhi & 7.5 & 7.5 & $1 \times 1$ & $1 \times 1-1.2 \times 2$ \\
\hline \multicolumn{5}{|l|}{ Grassland } \\
\hline Buenos Aires & 15 & 15 & $1.2 \times 1.2$ & $1 \times 1-2 \times 2$ \\
\hline Johannesburg & 4 & $0.6-4$ & $1 \times 1$ & $0.6 \times 0.6-1.2 \times 1.2$ \\
\hline Tehran & 2 & $2-3$ & NA & NA \\
\hline \multicolumn{5}{|l|}{ Desert } \\
\hline Cairo & 3 & $0.6-10$ & $0.6 \times 0.6$ & $0.3 \times 0.3-1.2 \times 3$ \\
\hline Dubai & 6 & $3-10$ & NA & NA \\
\hline Phoenix & 4 & $2.5-8$ & NA & NA \\
\hline \multicolumn{5}{|l|}{ Tundra } \\
\hline Murmansk & 7.5 & 7.5 & NA & NA \\
\hline Nuuk & NA & NA & NA & NA \\
\hline Reykjavik & NA & NA & $1 \times 1$ & $0.6 \times 0.6-2 \times 2$ \\
\hline \multicolumn{5}{|l|}{ Highland } \\
\hline Cusco & 3 & $3-4$ & NA & NA \\
\hline Lasha & NA & NA & NA & NA \\
\hline Quito & 3 & 3 & $0.3 \times 0.3$ & $0.3 \times 0.3-1.2 \times 1.2$ \\
\hline
\end{tabular}

$\mathrm{NA}=$ not applicable

\section{HOW REPRESENTATIVE IS THE DATA COLLECTED BY THE METHOD?}

The number of species recorded using this method will underestimate the total number of species. No sampling procedure, short of a $100 \%$ inventory, could identify all of the tree species in a city. The method was not intended to estimate the total number of tree species, but to identify the more commonly used street tree species. With the exception of the cities in the tundra biome, where few species can be used, the number of species recorded by the method represents only $20 \%$ to $30 \%$ of the street tree species. The relation between the number of species reported 
Table 4. Relationship between the number of tree species reported and observed in eight cities using the method reported in this article.

\begin{tabular}{llll}
\hline & \multicolumn{2}{c}{ Number of tree species } & \\
\cline { 2 - 3 } City & Reported & Observed & $\begin{array}{l}\text { Percent of } \\
\text { reported }\end{array}$ \\
\hline Bangkok & $127^{\mathrm{z}}$ & 33 & 26 \\
New York & $127^{\mathrm{y}}$ & 61 & 48 \\
Beijing & $170^{\mathrm{x}}$ & 32 & 19 \\
Buenos Aires & $160^{\mathrm{w}}$ & 40 & 25 \\
Dubai & $85^{\mathrm{v}}$ & 30 & 35 \\
Murmansk & $16^{\mathrm{u}}$ & 13 & 81 \\
Quito & $25^{\mathrm{t}}$ & 13 & 52 \\
\hline
\end{tabular}

${ }^{\mathrm{z}}$ Thaiutsa et al. 2000.

${ }^{\mathrm{y}}$ Barnard 2002.

${ }^{x}$ Beijing Annals Editor Board 2000.

"Valla 1999.

'Sharif 2003.

uKazakov 1999.

${ }^{\mathrm{t}}$ Gangotena et al. 1990. in published inventories and the number of species recorded in eight cities studied is shown in Table 4.

Although most cities have large numbers of tree species, relatively few species are commonly used. For example, in Chicago, five species make up $75.7 \%$ of the tree population (Nowak 1994) and in Beijing, the five most common species constituted $60.8 \%$ of the tree population (Yang et al. 2005). In a survey of Los Angeles, only 28 of a total of 175 species each comprised more than $1 \%$ of the total tree population (McPherson et al. 2003; Hodel, pers. comm.). In many cities, very few tree species have been used as street trees. The species used along streets often dominated the percentage of trees in an urban forest because the population of street trees outnumbers the population of trees in parks and other urban environments.

Although the method presented here recorded only $20 \%$ to $30 \%$ of the tree species in most of the cities for which $100 \%$ inventories were available, the method was successful in identifying the most commonly used tree species. For example, Thaiutsa et al. (2000) reports the five most common species in

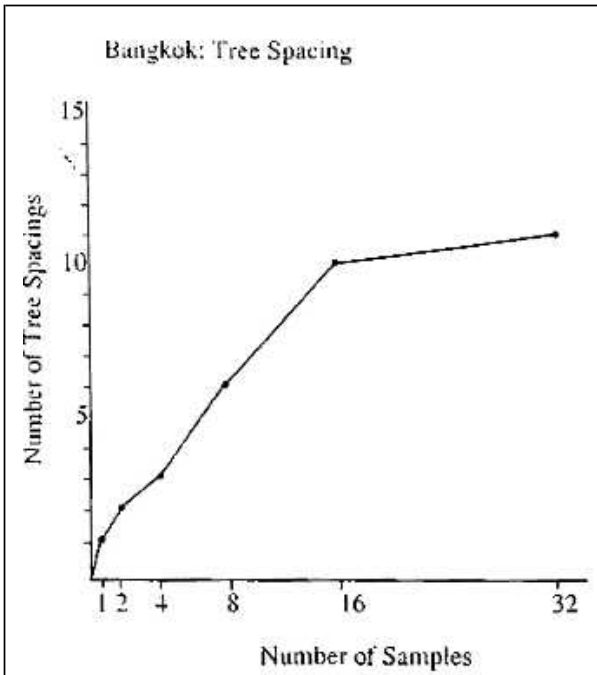

Bangkok: Tree Pir

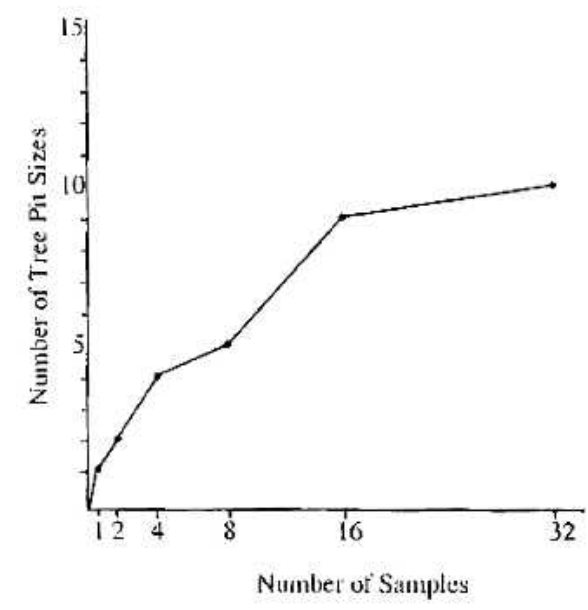

Johannesburg: Tree Spacing

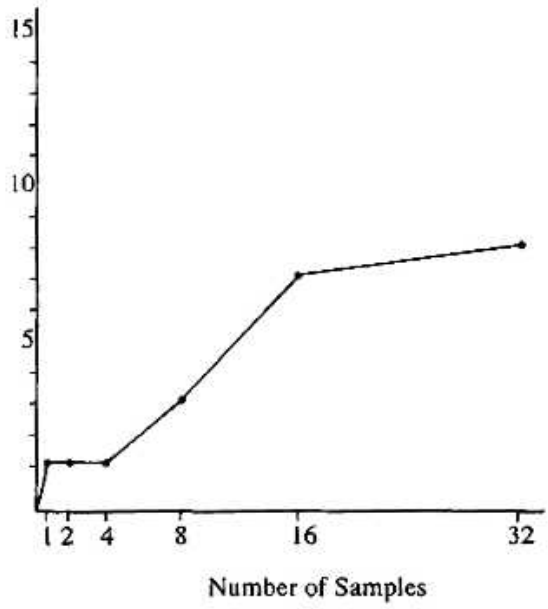

Johannesburg: Tree Pit

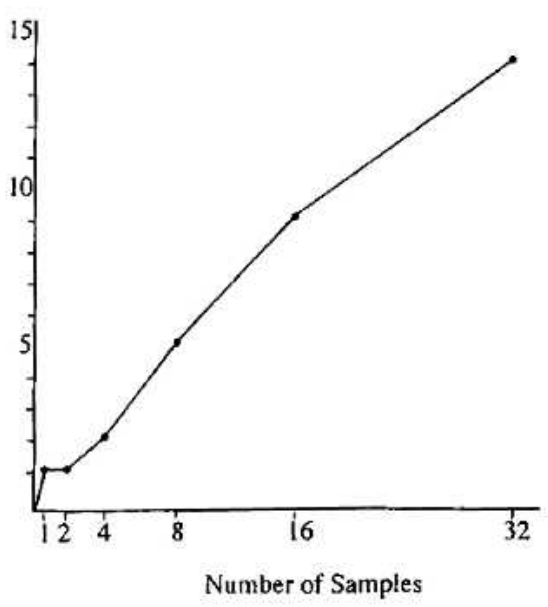

Singapore: Tree Spacing

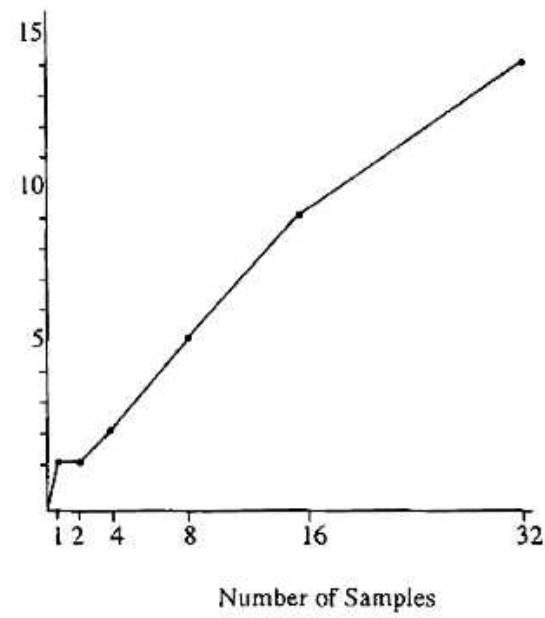

Singapore: Tree Pit

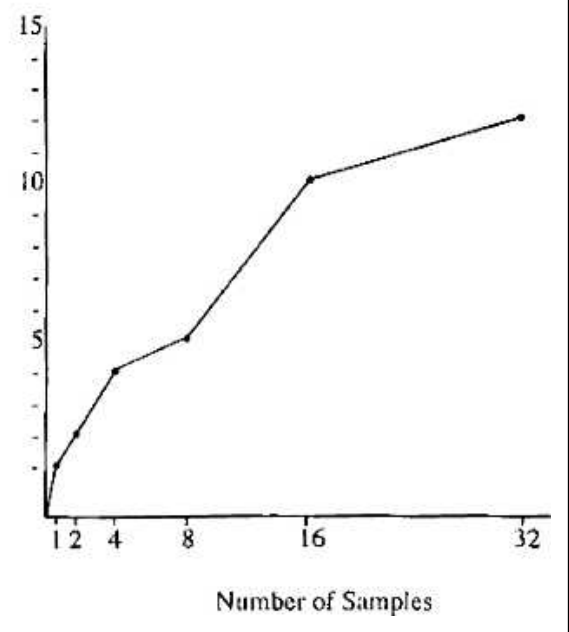

Figure 4. Number of tree spacings observed and number of tree pit sizes observed in three cities in relation to number of samples. 
Bangkok (on the basis of tree population) are angsana (Pterocarpus indicus), tamarind (Tabebuia rosea), golden shower (Cassia fistula), Honduras mahogany (Swietenia macrophylla), and bullet wood (Mimusops elengi). All of these were recorded in samples taken in Bangkok and three were among the top five in terms of frequency of occurrence. In Beijing, the five most common species are Japanese pagoda tree (Sophora japonica), Chinese white poplar (Populus tomentosa), Chinese juniper ( $\mathrm{Ju}$ niperus chinesis), black locust (Robinia pseudoacacia), and Chinese red pine (Pinus tabulaeformis) (Yang et al. 2005). The survey of Beijing using the method presented in this article found four of these five species among the top five species on the basis of their frequencies of occurrence. All five species were recorded by the method.

The species area curve procedure used by botanists to determine the size of a sample needed to identify the number of plant species in an area was applied to the data obtained on tree spacing and the dimensions of tree wells. In this procedure, the sample size is doubled and the number of species is plotted over each sample size (Mueller-Dombois and Ellenburg 1974). Curves plotted in this way level off and the point at which they begin to level off determines the size of the sample needed. This plotting procedure was used to see if the number of samples was adequate to capture the variety of tree spacings and tree well dimensions in the cities studied. Curves for three cities, representative of the patterns of curves for all of the cities studied, are presented here (Figure 4). Most cities followed the pattern illustrated by Bangkok and Johannesburg with regard to tree spacing. This pattern is characterized by a leveling off in the number of tree spacings recorded when the number of samples was increased for 16 to 32. This suggests that the sampling intensity was sufficient to capture $90 \%$ to $95 \%$ of the spacings between trees used in the cities. In contrast, the curve produced for Singapore does not illustrate a leveling off of the number of tree spacings observed. In this situation, a sample size greater than 32 would be required. Bangkok and Singapore showed a leveling off of the number of tree well sizes when the number of samples was increased from 16 to 32, suggesting that a sufficient number of samples had been taken in each city to record most of the range in tree well dimensions. Data from Johannesburg, however, suggest more than 32 samples are needed to encompass the range of tree well dimensions. During the data collection, it was obvious that some cities had strict control over the spacing of street trees and the size of tree wells, whereas other cities exhibited a much wider range in these design characteristics.

\section{GRAPHICALLY RECORDED INFORMATION}

The method presented here records information on urban forest structure in a graphic form. Such characteristics as the horizontal and vertical extent of tree canopies in relations to streets, sidewalks, and adjacent buildings can be quickly sketched but are difficult to summarize. The study of 33 of the world's urban forests generated hundreds of street and boulevard cross-sections sketches and street plans. They are very valuable in characterizing the structures of the urban forests. Unlike numeric data, this graphic information cannot be easily averaged nor compared using statistical analysis. One might morph the street crosssection sketches recorded in a particular urban environment to produce a "typical" or "average" cross-section using existing computer programs. These morphed cross-sections might turn out to be very characteristic for different cities. The individual cross-section sketches and street plans can be very meaningful to landscape architects and urban planners who often work with visual information. It was not within the scope of this study to "test" the usefulness of the information collected for designers, but I am convinced, through my work with landscape architects and urban planners, that they would find the structural information recorded graphically revealing and useful.

\section{CONCLUSIONS}

The method described in this article provides an efficient way to record information that is of interest to design professionals concerned with the composition and structure of urban forests. Larger sample sizes (greater than 40 sample sites), than the ones used in a study of the world's urban forests on which this article is based, will be needed to more accurately determine species composition and the range tree spacing and tree well dimension in most cities. However, the method provides a rapid way of recording data that can be used to calculate the relative frequency of occurrence of tree species, document dimensions of tree spacing, and planting sites. The graphic representation of additional urban forest structural information can provide a useful record for landscape architects and urban planners who normally work with both quantitative and visual data.

\section{LITERATURE CITED}

Arnold, H.F. 1993. Trees in Urban Design. Van Nostrand Reinhold, New York, NY.

Barnard, E.S. 2002. New York City Trees. New York: Columbia University Press.

Beijing Annals Editorial Board. 2000. Landscape plants. In: Beijing Annals Editorial Board (Eds.), Beijing Annals, Vol. 16 Municipal Administration, Coy 52, Gardens and Afforestation Annals. Beijing Publishing House, Beijing, China, pp. 337-384 (in Chinese).

Gangotena, et al. 1990. Tree species along major arterial and residential streets of Quito. Quito: Department of Parks and Gardens (in Spanish). In: Murray S. 1999. "Human Nature," the shaping of the urban ecosystem in spontaneous settlements of Quito, Ecuador. PhD Dissertation. University of California, Berkeley.

Gruffydd, B. 1987. Tree Form, Size, and Colour: A Guide to Selection, Planting, and Design. E. \& F. N. Spon, New York, NY.

Jacobs, A.B., E. MacDonald, and Y. Rofe. 2002. The Boulevard Book. The MIT Press, Cambridge, MA.

Kazakov, L. 1999. Trees Growing in Murmansk. Polar Arctic Botanical Garden, Apatity, Russia.

Littlewood, M. 1988. Tree Detailing. Butterworth Architecture, London, UK.

McBride, J.R. 2000. Urban Forestry: What we can learn from cities around the world. Proceedings of the XIIth National Urban and Community Forest Conference, Seattle, WA. pp. 39-43.

- 2003. Palo Alto Tree Study. Report to the City of Palo Alto Planning Department, Palo Alto, CA.

McPherson, E.G., G. Gonzalez, G. Monfette, and R. Lorenzen. 2003. Expanding street tree canopy cover and repairing sidewalks in the City of Los Angeles. Western Arborist 29:1-4.

Miller, R.W. 1997. Urban Forestry. Prentice Hall, Upper Saddle River, NJ.

Mueller-Dombois, D., and H. Ellenburg. 1974. Aims and Methods of Vegetation Ecology. J. Wiley, New York, NY.

Nowak, D.J. 1994. Urban forest structure: The state of Chicago's urban forest, pp. 3-18. In: McPherson, E.G., D.J. Nowak, and R.A. Rowntree (Eds.). Chicago's Urban Forest Ecosystem: Results of the Chi- 
cago Urban Forest Climate Project. Gen. Tech, Rep. NE-186. US Department of Agriculture, Forest Service, Northeastern Forest Experiment Station, Radnor, PA.

Nowak, D.J., D.E. Crane, J.C. Stevens, and R.E. Hoehn. 2003. The Urban Forest Effects (UFORE) Model: Field Data Collection Manual. USAD Forest Service, Northeastern Research Station, 5 Moon Library, SUNY_ESF, Syracuse, NY.

Panahi, P., M. Zobeiri, S.M. Hoseini, and M. Makhdoum. 2003. Determination of appropriate inventory methods in urban forestry. Iranian Journal of Natural Resources 56:191-199.

Rowntree, R.A. 1984. Ecology of the urban forest-Introduction to Part I. Urban Ecology 8:1-11.

Sharif, M.E. 2003. Trees Occurring in Dubai. Dubai Municipality, Public Parks and Horticulture Department.

Thaiutsa, B. 2000. Street Trees of Bangkok. Asksorn Siam Printing, Bangkok, Thailand.

Trowbridge, P.J., and N.L. Bassuk. 2004. Trees in the Urban Landscape: Site Assessment, Design, and Installation. John Wiley, Hoboken, NJ.

Tsuru, K. (Ed.). 1992. Elements and Total Concept of Urban Tree Design. Graphic-sha, Tokyo, Japan.

Urban, J. 1989. New techniques in urban tree planting. Journal of Arboriculture 15:281-284.

Valla, J.J. 1999. Arboles Urbanos. Buenos Aires: Edicion L.O.L.A. (in Spanish).

Yang, J., J.R. McBride, J. Zhou, and Z. Sun. 2005. The urban forest in Beijing and its role in air pollution reduction. Urban Forestry and Urban Greening 3:65-78.

Zion, R.L. 1995. Trees for Architecture and Landscape. Van Nostrand Reinhold, New York, NY.
Joe R. McBride

Professor

Department of Landscape Architecture and Environmental Planning

University of California

Berkeley, CA 94720-20003, U.S.

jrm@nature.berkeley.edu

Résumé. Une méthode combinant la collection de données numériques avec la préparation de plans et de coupes transversales d'arbres et de rues, et ce en se basant sur l'inventaire de 33 forêts urbaines à travers le monde, est revue. La combinaison peut permettre un design professionnel avec de l'information graphique sur la structure de la forêt urbaine qui n'est pas colligée avec des méthodes plus traditionnelles d'inventaire de la forêt urbaine.

Zusammenfassung. In einem Rückblick wird eine Methode zur Kombination numerischer Datensammlungen mit Präparationen von Straßenbaumquerschnitten und Plänen, basierend Erhebungen von weitweit 33 verschiedenen urbanen Wäldern dargestellt. Die Kombination kann professionelles Design mit graphischen Informationen über urbane Forststrukturen liefern, die nicht durch traditionelle Erhebungsverfahren gesammelt wurden.

Resumen. Se revisa un método que combina una colección de datos numéricos con la preparación de planos o secciones de árboles urbanos, con base en inventarios de 33 bosques urbanos alrededor del mundo. La combinación puede proveer diseños profesionales con información gráfica en la estructura del bosque urbano, no colectada por métodos tradicionales para inventarios de bosques urbanos. 